\title{
Characterization of 20 new EST-SSR markers for northern red oak (Quercus rubra L.) and their transferability to Fagus sylvatica L. and six oak species of section Lobatae and Quercus
}

\author{
Markus Müller, Oliver Gailing $\$$
}

Müller M., Gailing O., 2018. Characterization of 20 new EST-SSR markers for northern red oak (Quercus rubra L.) and their transferability to Fagus sylvatica L. and six oak species of section Lobatae and Quercus. Ann. For. Res. 61(2): 211-222.

Abstract. Northern red oak (Quercus rubra L.) is widely distributed in the eastern United States and southeastern Canada. It has also been introduced to Europe, where it has become an economically important plantation species now. Despite growing genomic resources, the number of available EST-SSR (expressed sequence tag - simple sequence repeat) markers for Q. rubra is still limited. Here, we used existing sequence information to provide a new set of EST-SSRs for northern red oak. In total, we report 20 polymorphic EST-SSRs, for which performance was evaluated in three $Q$. rubra populations from different regions in Michigan. We further tested the transferability of these markers to six additional oak species of section Lobatae (Quercus ellipsoidalis E.J. Hill, and Quercus georgiana M.A. Curtis) and Quercus (Quercus robur L., Quercus alba L., Quercus pedunculiflora K. Koch, and Quercus petraea (Matt.) Liebl.), as well as to European beech (Fagus sylvatica L.). The reported markers can be used in future population genetic studies.

Keywords: microsatellites, Fagaceae, genetic diversity

Authors. University of Goettingen, Faculty for Forest Sciences and Forest Ecology, Forest Genetics and Forest Tree Breeding, Center for Integrated Breeding Research, Büsgenweg 2, 37077 Göttingen, Germany.

§ Corresponding author: Oliver Gailing (ogailin@gwdg.de)

Manuscript received September 20, 2018; revised December 26, 2018; accepted December 29, 2018; online first December 31, 2018.

\section{Introduction}

Northern red oak (Quercus rubra L.) is an important timber species that is widely distributed in the eastern United States and southeastern Canada, and grows under various en- vironmental conditions within its distribution range (USDA NRCS 2002, Magni et al. 2005). It belongs to section Lobatae (red oaks), which members are native only to the Americas. Northern read oak has been introduced to Europe, where it has become an economically 
important plantation species in several countries now.

Climate change is expected to significantly impact forest ecosystems in Europe, influencing the vegetation period, growth, health, and distribution of trees (European Environment Agency (EEA) 2012). Forest management can help forest ecosystems to adapt to these new conditions (Bolte et al. 2009). One component of adaptive forest management could be the promotion of non-native tree species, such as Q. rubra, that may be better adapted to future environmental conditions (Roloff \& Grundmann 2008, Bolte et al. 2009). Currently, growing genomic and transcriptomic resources are becoming available for northern red oak (The Hardwood Genomics Project, Konar et al. 2017). Resources such as transcriptome data can be used to derive EST-SSR (expressed sequence tag - simple sequence repeat) markers. These markers usually show high transferability rates among taxa (Ellis \& Burke 2007), and, due to their location in coding or closely linked regions, are candidates for the study of local adaptation. For instance, EST-SSRs can be used in genetic association studies, in which markers are identified that are significantly associated with adaptive traits or environmental variables (Balding 2006, Rellstab et al. 2015). Often these approaches are combined with outlier analyses, in which markers under selection show higher or lower differentiation among populations than expected under neutral assumptions (Helyar et al. 2011, Narum \& Hess 2011). The number of available EST-SSRs for Q. rubra, however, is still limited (Sullivan et al. 2013).

Therefore, the aim of our study was to take advantage of available EST-SSR sequence information, and provide a new set of ESTSSR markers for northern red oak. The performance of the markers was evaluated in three Q. rubra populations from different regions in Michigan. In total, we report 20 markers that are polymorphic in $Q$. rubra. We further tested the transferability of these markers to six other oak species of section Lobatae (Quercus el212 lipsoidalis E.J. Hill, Quercus georgiana M.A. Curtis), and Quercus (Quercus robur L., Quercus alba L., Quercus pedunculiflora K. Koch, and Quercus petraea (Matt.) Liebl.), as well as to European beech (Fagus sylvatica L.).

\section{Materials and methods}

\section{Marker analysis}

Initially, 40 EST-SSRs were tested for amplification and polymorphism in four Q. rubra samples. Primer sequences were obtained from the Hardwood Genomics Project (https:// www.hardwoodgenomics.org/Transcriptome-assembly/1963023?tripal_pane=group summary_tripalpane). Successfully amplified polymorphic markers were further evaluated in 96 samples of three different Q. rubra populations (FC-A, HMR-IH, and MTU-1) located in different regions in Michigan. DNA extracted from leaf material of the populations was obtained from a previous study (Lind \& Gailing 2013). Population FC-A was located in the Baraga Plains region (latitude: $46^{\circ} 39^{\prime} 9.407^{\prime \prime} \mathrm{N}$, longitude: $\left.88^{\circ} 30^{\prime} 6.962^{\prime \prime} \mathrm{W}\right)$, the population HMR-IH was located in the Huron Mountain Reserve (latitude: $46^{\circ} 51^{\prime} 12.884^{\prime \prime} \mathrm{N}$, longitude: $87^{\circ} 50^{\prime} 42.824^{\prime \prime} \mathrm{W}$ ), and the MTU-1 population was located in Houghton (latitude: 476'24.649'”N, longitude: 88³2'51.209'”W). Furthermore, the transferability of the markers to six other oak species and European beech was tested. The markers were tested in each five samples of the species Q. ellipsoidalis, Q. georgiana, and $Q$. robur, as well as in two samples of each $Q$. alba, $Q$. pedunculiflora, $Q$. petraea, and $F$. sylvatica.

For genotyping, a PCR mix was prepared consisting of $1 \mu \mathrm{l}$ DNA (ca. $0.6 \mathrm{ng} / \mu \mathrm{l}$ ), $1.5 \mu \mathrm{l}$ 10x reaction buffer $\mathrm{B}$ (Solis BioDyne, Tartu, Estonia), $1.5 \mu \mathrm{lgCl}_{2}(25 \mathrm{mM}), 1 \mu \mathrm{l}$ dNTPs (2.5 mM each dNTP), $0.2 \mu \mathrm{l}(5 \mathrm{U} / \mu \mathrm{L}) \mathrm{HOT}$ FIREPol Taq DNA polymerase (Solis BioDyne, Tartu, Estonia), $0.2 \mu \mathrm{l}$ (5 picomole $/ \mu \mathrm{l})$ tailed forward primer (Schuelke 2000, Kubi- 
siak et al. 2013), $0.5 \mu \mathrm{l}$ (5 picomole/ $\mu 1)$ PIGtailed reverse primer (Brownstein et al. 1996), $1 \mu \mathrm{l}(5$ picomole $/ \mu \mathrm{l})$ dye labeled (6-FAM) M13 primer, and $5.5 \mu 1 \mathrm{H}_{2} \mathrm{O}$. Fragments were separated on an ABI 3130xl Genetic Analyzer (Applied Biosystems, Foster City, USA) using GS 500 ROX (Applied Biosystems, Foster City, USA) as an internal size standard. Allele scoring was conducted using the GeneMapper 4.1 software (Applied Biosystems, Foster City, USA). The following touchdown PCR program was used: an initial denaturation of $95^{\circ} \mathrm{C}$ for $15 \mathrm{~min}$, followed by 10 touchdown cycles of $94{ }^{\circ} \mathrm{C}$ for $1 \mathrm{~min}, 60^{\circ} \mathrm{C}\left(-1^{\circ} \mathrm{C}\right.$ per cycle $)$ for $1 \mathrm{~min}$, and $72{ }^{\circ} \mathrm{C}$ for $1 \mathrm{~min}, 25$ cycles of 94 ${ }^{\circ} \mathrm{C}$ for $1 \mathrm{~min}, 50{ }^{\circ} \mathrm{C}$ for $1 \mathrm{~min}$, and $72{ }^{\circ} \mathrm{C}$ for 1 min, and a final extension step of $72{ }^{\circ} \mathrm{C}$ for 20 min. For genotyping of the successfully amplified markers, the loci were combined in five different multiplexes (multiplex 1: Qr1423, Qr2927, Qr6333b, and Qr6859; multiplex 2: FS_C1702, Qr0237, Qr0332, and Qr6783; multiplex 3: FS_C2361, Qr1266, Qr3552, and Qr3173; multiplex 4: Qr0057, Qr1824, Qr5117, and Qr5623; multiplex 5: FS_C2660, FS_C2791, FS_C8183, and Qr2660).

\section{Data analysis}

The genetic diversity indices number of alleles $\left(N_{a}\right)$, observed heterozygosity $\left(H_{o}\right)$, and expected heterozygosity $\left(H_{e}\right)$ for the different markers, as well as the fixation index $\left(F_{S T}\right)$ among populations were calculated with the GenAlEx 6.501 software (Peakall \& Smouse 2006, 2012). Significant differences of $N_{a}, H_{o}$, and $H_{e}$ among populations were tested using the Kruskal-Wallis test with multiple comparisons implemented in the R package pgirmess 1.6.7 (Giraudoux 2017). The inbreeding coefficient $\left(\mathrm{F}_{\text {IS }}\right.$ ) (Weir \& Cockerham 1984) was calculated with FSTAT 2.9.3 (Goudet 1995). $P$-values $(\alpha$ $=0.05$ ) were corrected for multiple comparisons using a sequential Bonferroni correction (Rice 1989). Genepop 4.7 (Rousset 2008) was used to calculate linkage disequilibrium (LD) for each pair of loci in the three populations with the following parameters for the Markov chain: 10,000 dememorisation steps, 100 batches, and 5000 iterations per batch. A Bonferroni correction on the original $p$-value $(\alpha=$ 0.05 ) was applied to correct for multiple testing. Population structure was inferred using the STRUCTURE 2.3.4 software (Pritchard et al. 2000). The admixture model and correlated allele frequencies were selected. A burn-in period of 50,000 and Markov chain Monte Carlo (MCMC) replicates of 100,000 were used. Potential clusters $(K)$ from 1 to 6 were tested using 10 iterations. The $\Delta K$ method (Evanno et al. 2005) was applied to infer the most likely number of $K$ with the STRUCTURE HARVESTER 0.6.94 software (Earl \& vonHoldt 2012). The CLUMPAK software (Kopelman et al. 2015) was used for summation and graphical representation of the STRUCTURE results. Clustering of populations was further analyzed using a principle coordinate analysis (PCoA) with the covariance standardization method implemented in GenAlEx (Peakall \& Smouse 2006, 2012). To detect potential deviations from neutral expectations, an outlier analysis was performed using the LOSITAN 1.0 software (Antao et al. 2008). LOSITAN was run with 70,000 simulations, the step-wise mutation model, and a FDR (false discovery rate) of 0.1 . Annotation of the sequences, in which the SSR loci were located, was performed using similarity searches against the NCBI (National Center for Biotechnology Information) nucleotide collection (nr) database with BLASTN 2.8.0+ (Altschul et al. 1997).

\section{Results}

Of the 40 initially tested EST-SSRs, 20 markers were polymorphic, 5 were monomorphic (Table 1), and 15 markers did not amplify (Table S1 - Supporting Information). The 20 polymorphic markers were used to genotype 96 individuals of three $Q$. rubra populations 


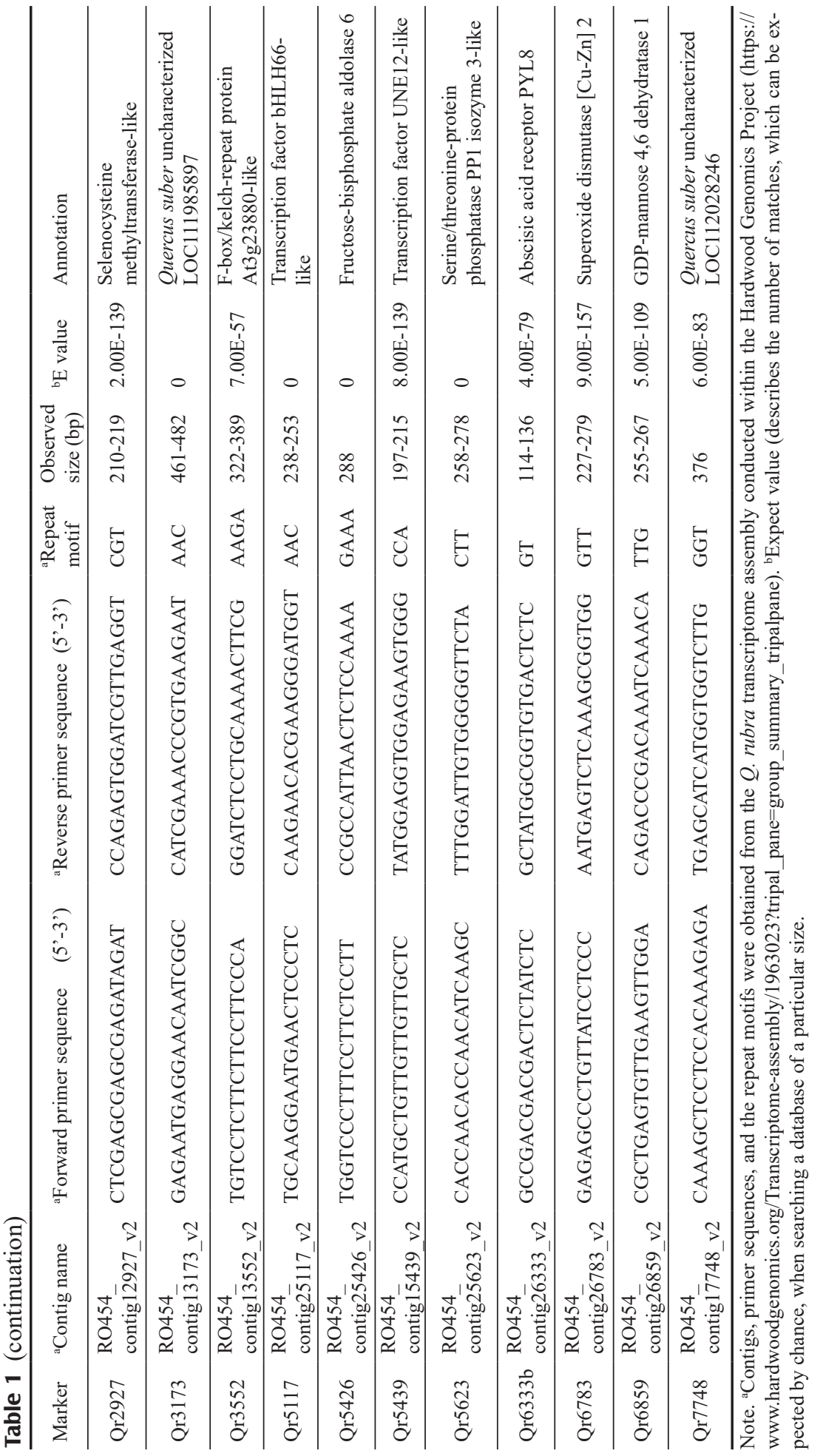


from different regions in Michigan. The number of alleles $\left(N_{a}\right)$ for the different loci ranged from 2 to 13 in population FC-A (mean $N_{a}$ : 5.0), from 2 to 13 in population HMR-IH (mean $N_{a}: 5.8$ ), and from 2 to 15 in population MTU-1 (mean $\left.N_{a}: 5.5\right)$ (Table 2). The observed heterozygosity $\left(H_{o}\right)$ ranged from 0.147 for marker Qr2361 in population MTU-1 to 0.939 for marker Qr6783 in the same population. The mean values of $H_{o}$ over all loci were 0.483 for FC-A, 0.620 for HMR-IH, and 0.566 for MTU-1. The expected heterozygosity $\left(H_{e}\right)$ ranged from 0.136 for marker Qr2361 in population MTU-1 to 0.907 for marker Qr6783 in population HMR-IH. The mean values of $H_{e}$ were 0.597 for FC-A, 0.623 for HMR-IH, and 0.618 for MTU-1 (Table 2). All genetic diversity indices were not significantly different among populations. The $F_{I S}$ value was significantly different from zero only for marker Qr5623 in population MTU-1. Over all loci, the $F_{I S}$ values of the populations FC-A and MTU-1 were significantly different from zero (Table 2). Genetic differentiation $\left(F_{S T}\right)$ among populations ranged from 0.002 for marker Qr5623 to 0.127 for marker Qr1266. The mean differentiation among populations was $0.041(\mathrm{p}<0.05)$ (Table 2). No $F_{S T}$ - outlier loci were detected. Differentiation among populations was also detected with the STRUCTURE and principle coordinate analyses. The STRUCTURE analysis revealed a most likely number of clusters of $K=2$ (Fig. S1 - Supporting Information). Population FC-A was clearly separated from HMR-IH and MTU-1 (Fig. 1). A separation of FC-A from the other two populations was also revealed by the PCoA, albeit less pronounced (Fig. 2). Significant

Table 2 Genetic diversity indices based on EST-SSRs for the populations

\begin{tabular}{|c|c|c|c|c|c|c|c|c|c|c|c|c|c|c|c|c|}
\hline \multirow[b]{2}{*}{ Marker } & \multirow[b]{2}{*}{$F_{S T}$} & \multicolumn{5}{|c|}{ FC-A } & \multicolumn{5}{|c|}{ HMR-IH } & \multicolumn{5}{|c|}{ MTU-1 } \\
\hline & & $N$ & $N_{a}$ & $H_{o}$ & $H_{e}$ & $F_{I S}$ & $N$ & $N_{a}$ & $H_{0}$ & $H_{e}$ & $F_{I S}$ & $N$ & $N_{a}$ & $H_{o}$ & $H_{e}$ & $F_{I S}$ \\
\hline FS_C1702 & $0.038^{*}$ & 28 & 5 & 0.500 & 0.679 & 0.281 & 32 & 5 & 0.750 & 0.693 & -0.067 & 34 & 6 & 0.647 & 0.593 & -0.077 \\
\hline FS_C2361 & $0.108 *$ & 26 & 2 & 0.538 & 0.473 & -0.118 & 33 & 2 & 0.303 & 0.257 & -0.164 & 34 & 2 & 0.147 & 0.136 & -0.065 \\
\hline FS_C2660 & $0.062 *$ & 28 & 5 & 0.500 & 0.582 & 0.158 & 33 & 5 & 0.818 & 0.732 & -0.103 & 35 & 5 & 0.771 & 0.769 & 0.011 \\
\hline FS_C2791 & 0.018 & 28 & 2 & 0.286 & 0.245 & -0.149 & 33 & 3 & 0.424 & 0.404 & -0.033 & 35 & 2 & 0.400 & 0.382 & -0.033 \\
\hline FS_C8183 & 0.011 & 28 & 5 & 0.571 & 0.582 & 0.036 & 33 & 6 & 0.758 & 0.697 & -0.071 & 35 & 5 & 0.600 & 0.638 & 0.073 \\
\hline Qr0057 & 0.022 & 26 & 6 & 0.462 & 0.652 & 0.310 & 33 & 5 & 0.758 & 0.647 & -0.155 & 34 & 7 & 0.706 & 0.743 & 0.064 \\
\hline Qr0237 & $0.051 *$ & 23 & 7 & 0.391 & 0.494 & 0.230 & 33 & 8 & 0.788 & 0.793 & 0.022 & 34 & 8 & 0.735 & 0.730 & 0.007 \\
\hline Qr0332 & $0.046^{*}$ & 26 & 5 & 0.577 & 0.708 & 0.204 & 33 & 6 & 0.727 & 0.733 & 0.023 & 34 & 6 & 0.765 & 0.716 & -0.053 \\
\hline Qr1266 & $0.127 *$ & 26 & 3 & 0.385 & 0.508 & 0.261 & 33 & 3 & 0.424 & 0.430 & 0.028 & 34 & 4 & 0.382 & 0.544 & 0.310 \\
\hline Qr1423 & 0.025 & 27 & 3 & 0.185 & 0.497 & 0.639 & 33 & 3 & 0.273 & 0.330 & 0.189 & 34 & 3 & 0.353 & 0.424 & 0.182 \\
\hline Qr1824 & $0.045^{*}$ & 24 & 9 & 0.583 & 0.857 & 0.338 & 33 & 11 & 0.788 & 0.801 & 0.031 & 34 & 11 & 0.824 & 0.846 & 0.042 \\
\hline Qr2927 & 0.013 & 21 & 3 & 0.381 & 0.439 & 0.156 & 32 & 4 & 0.531 & 0.482 & -0.087 & 34 & 3 & 0.382 & 0.436 & 0.139 \\
\hline Qr3173 & $0.073 *$ & 26 & 6 & 0.462 & 0.511 & 0.116 & 32 & 8 & 0.906 & 0.805 & -0.111 & 32 & 7 & 0.781 & 0.811 & 0.053 \\
\hline Qr3552 & 0.028 & 20 & 3 & 0.200 & 0.515 & 0.627 & 32 & 3 & 0.156 & 0.330 & 0.537 & 33 & 3 & 0.333 & 0.417 & 0.216 \\
\hline Qr5117 & 0.033 & 26 & 3 & 0.462 & 0.607 & 0.257 & 33 & 6 & 0.545 & 0.625 & 0.143 & 34 & 5 & 0.765 & 0.730 & -0.033 \\
\hline Qr5439 & 0.037 & 28 & 4 & 0.607 & 0.654 & 0.089 & 33 & 6 & 0.636 & 0.718 & 0.128 & 35 & 6 & 0.743 & 0.762 & 0.040 \\
\hline Qr5623 & 0.002 & 28 & 4 & 0.321 & 0.601 & 0.479 & 33 & 5 & 0.424 & 0.579 & 0.281 & 35 & 4 & 0.286 & 0.565 & $0.505^{*}$ \\
\hline Qr6333b & $0.031 *$ & 28 & 8 & 0.857 & 0.835 & -0.008 & 32 & 9 & 0.906 & 0.867 & -0.030 & 34 & 10 & 0.765 & 0.859 & 0.125 \\
\hline Qr6783 & $0.041 *$ & 23 & 13 & 0.826 & 0.875 & 0.078 & 33 & 13 & 0.879 & 0.907 & 0.047 & 33 & 15 & 0.939 & 0.888 & -0.043 \\
\hline Qr6859 & 0.020 & 28 & 4 & 0.571 & 0.635 & 0.118 & 33 & 4 & 0.606 & 0.629 & 0.053 & 35 & 4 & 0.543 & 0.698 & 0.236 \\
\hline $\begin{array}{l}\text { Mean/ } \\
\text { all loci }\end{array}$ & $0.041 *$ & 25.9 & 5 & 0.483 & 0.597 & $0.210^{*}$ & & 5.8 & 0.620 & 0.623 & 0.020 & & 5 & 0.566 & 0.618 & $0.079^{*}$ \\
\hline
\end{tabular}

Note. Abbreviations: $F_{S T}$ - fixation index, $N$ - number of individuals, $N_{a}$ - number of alleles, $H_{o}$ - observed heterozygosity, $H_{e}$ - expected heterozygosity, $F_{I S}$ - inbreeding coefficient, ${ }^{*} F_{I S}^{a}$ or $F_{S T}$ significantly different from zero after Bonferroni correction. 


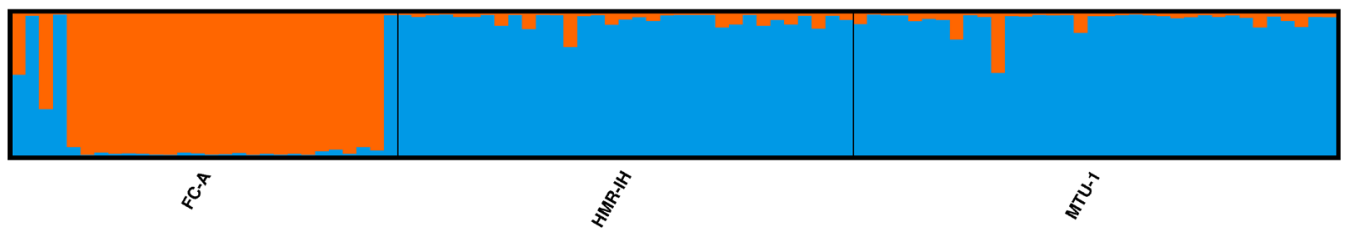

Figure 1 Clustering of individuals of the three populations

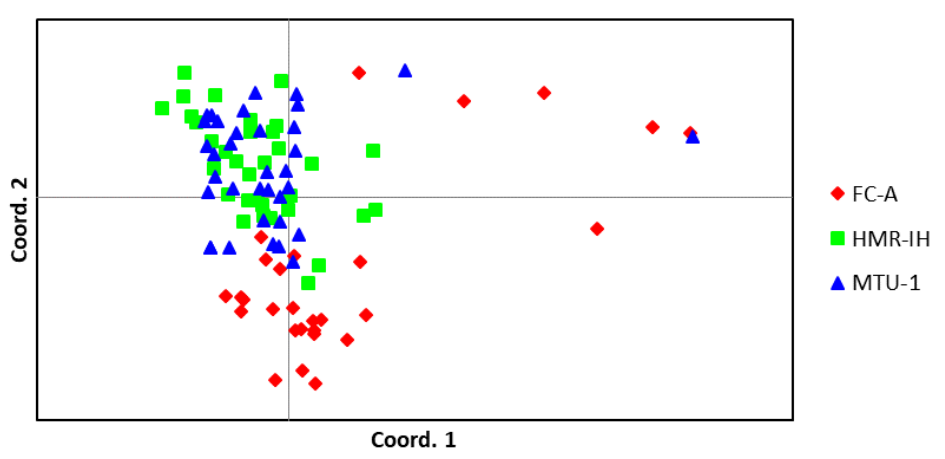

Figure 2 Principal coordinates analysis
LD was only observed between the markers Qr2791 and Qr3173 in population FC-A, and between markers Qr2927 and Qr6783 in population HMR-IH.

The transferability of the 20 polymorphic markers in Q. rubra to six other oak species and European beech was successfully tested (Table 3). All loci, except for marker Qr3552 to $Q$. robur, were successfully transferred to all tested oak species ( $Q$. ellipsoidalis, $Q$. georgiana, $Q$. robur, $Q$. alba, $Q$. pedunculiflo$r a$, and $Q$. petraea), and most of the markers were polymorphic. In total, 13 of the 20 markers $(65 \%)$ were transferable to $F$. sylvatica, and five of them were polymorphic. Markers FS_C1702, FS_C2361, FS_C2660, FS_2791, and FS_8183 have been tested for amplification in $F$. sylvatica before. Like in our study, all of these markers amplified in F. sylvatica, but only FS_C2361 was polymorphic.

\section{Discussion}

The performance of 20 successfully amplified and polymorphic ESTSSR markers was evaluated in three $Q$. rubra populations from different regions in Michigan. A high genetic diversity was revealed for all populations (Table 2). Other studies, however, showed slightly higher genetic diversity estimates for the same and other $Q$. rubra populations. For instance, based on seven EST-SSRs, Lind \& Gailing (2013) reported a mean number of alleles per locus of 11 , a mean observed heterozygosity of 0.610 , and a mean expected heterozygosity (unbiased expected heterozygosity (Peakall \& Smouse 2006) of 0.700. Based on 18 EST-SSRs, also Sullivan et al. (2013) reported slightly higher values (mean $N_{a}: 7$, mean $H_{o}: 0.700$, mean $H_{e}: 0.700$ ). Hence, the EST-SSRs tested in our study, seem on average to be slightly less variable than previously reported EST-SSRs for Q. rubra, but variable enough for future population genetic studies. Over all loci, the $F_{I S}$ values of the populations FC-A and MTU-1 were significantly different from zero. Nevertheless, since all markers (except Qr5623 for MTU-1) showed $F_{I S}$ values not different from zero, the populations are likely not affected by inbreeding. A low but significant genetic differentiation among populations was detected $\left(F_{S T}: 0.041\right.$, $\mathrm{p}<0.05)$. This is in agreement with other studies in forest tree species including $Q$. rubra 


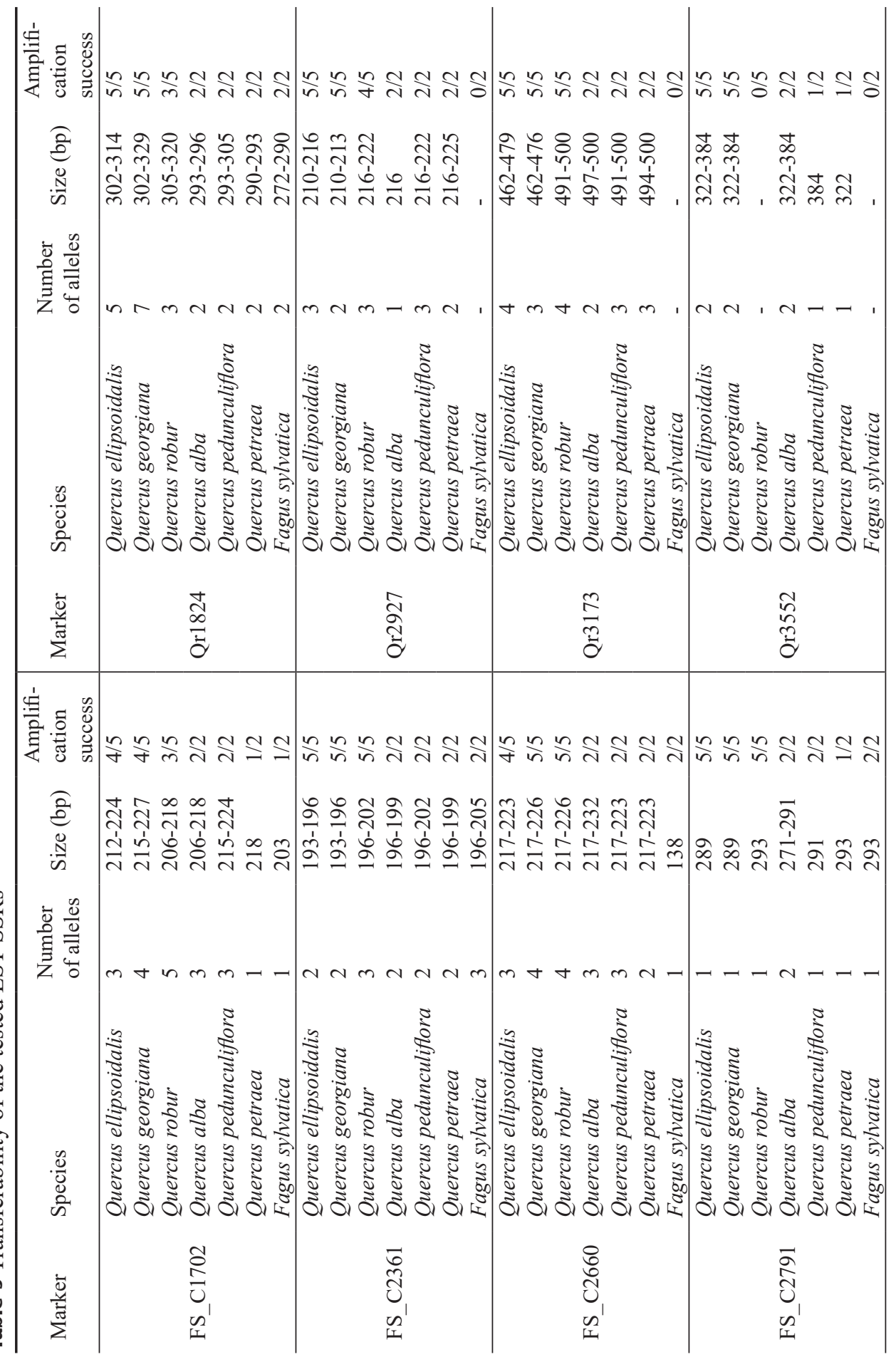




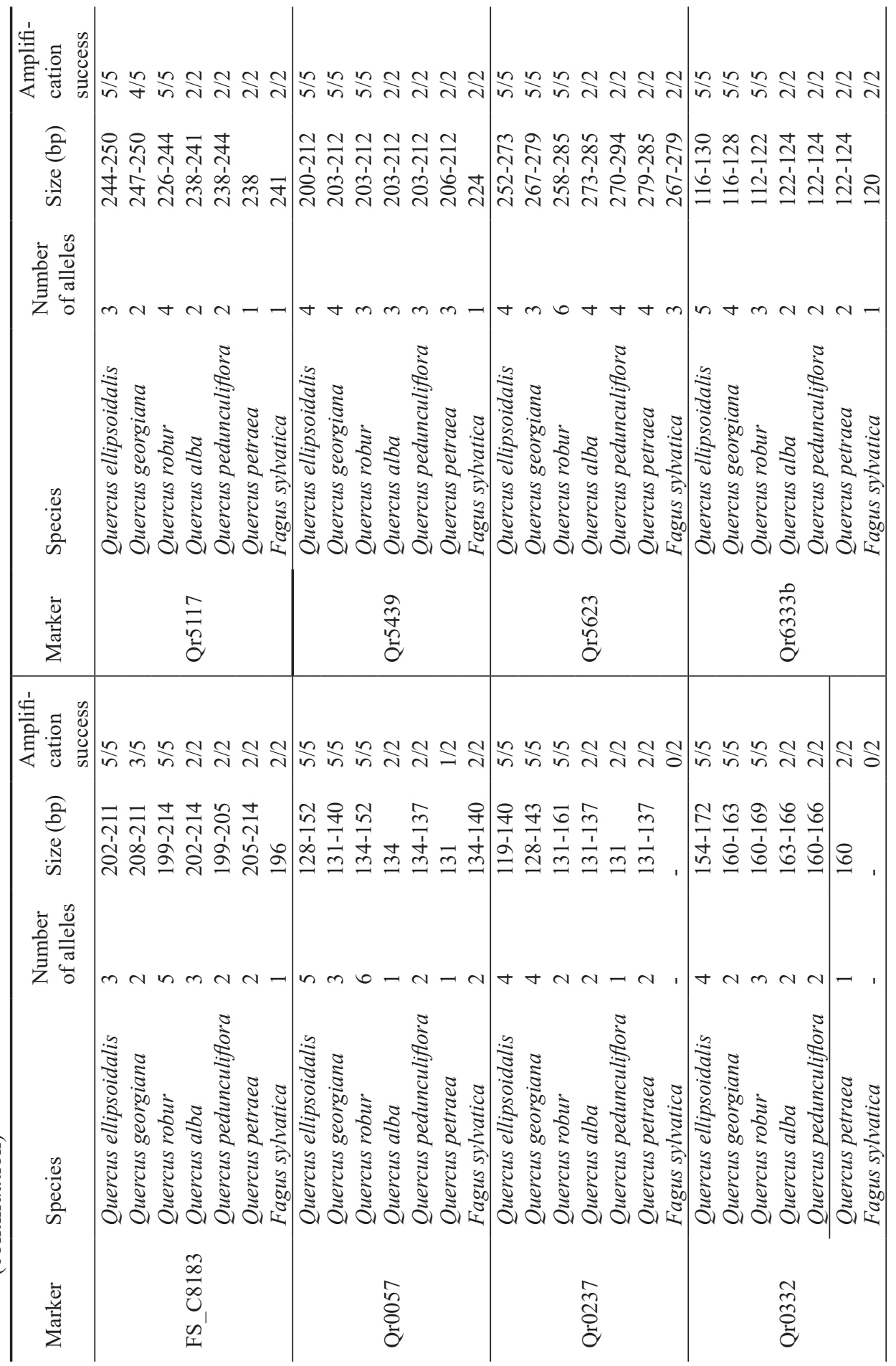




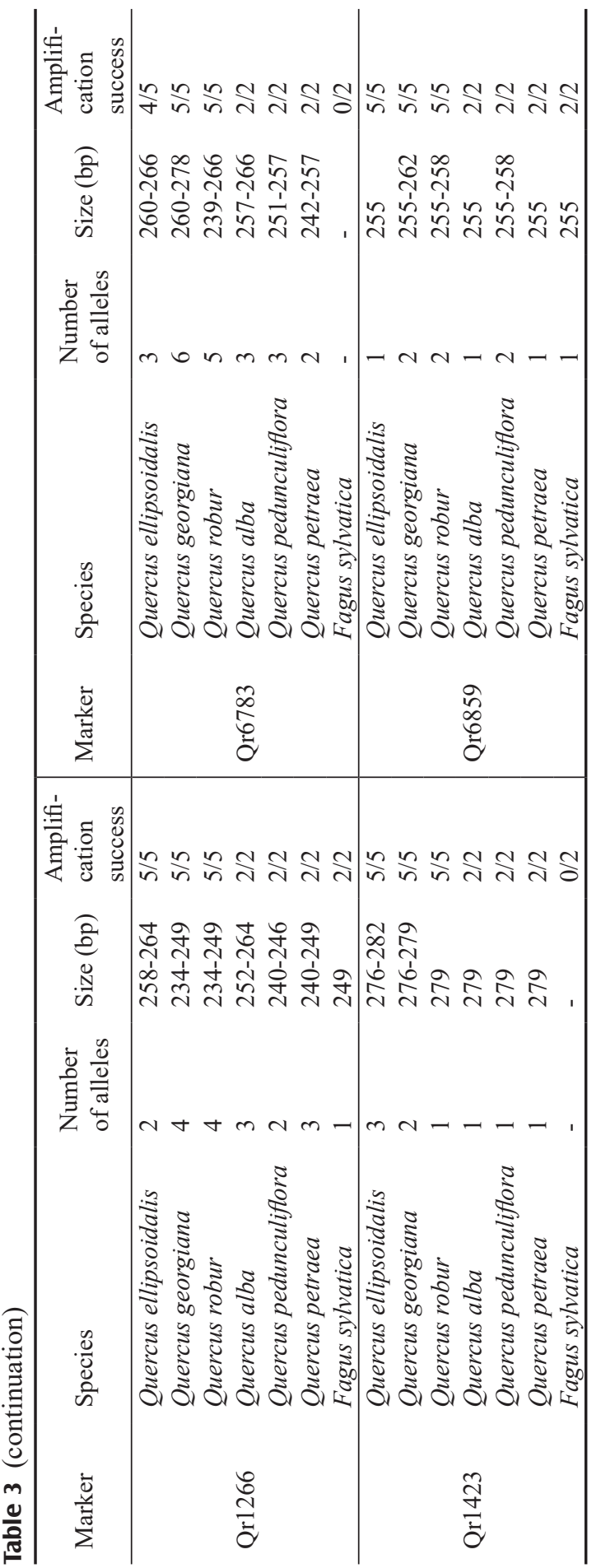

(e.g., Lind \& Gailing 2013, Sullivan et al. 2013, Lalagüe et al. 2014, Müller \& Finkeldey 2016). The STRUCTURE analysis and, at a lower level, the PCoA, showed a separation of population FC-A from the other two populations, HMR-IH and MTU-1. The reason for this differentiation remains open.

The transferability of the reported EST-SSR markers in Q. rubra to six other oak species and European beech was successfully tested. In general, a high transferability of EST-SSRs is expected among taxa (Ellis \& Burke 2007). In agreement with this, all loci were successfully transferred to all tested oak species (except marker Qr3552 to Q. robur). Thus, the amplification success was generally not lower in oaks belonging to section Quercus (Q. alba, Q. robur, and $Q$. pedunculiflora), despite the markers were transferred from $Q$. rubra, which belongs to section Lobatae. The transferability to F. sylvatica, however, was lower. In total, 13 of 20 markers (65\%) were transferable to this species. The transferability rates are in agreement with other studies. For instance, Steinkellner et al. (1997) found transferability rates for SSRs developed in Q. petraea of $100 \%$ for $Q$. robur and $Q$. pubescens Willd., of $64 \%$ for Quercus cerris L., of $47 \%$ for Quercus palustris Münchh., Q. rubra and Castanea sativa Mill., and of $24 \%$ for $F$. sylvatica. Barreneche et al. (2004) found that SSRs developed for Q. rubra, Q. petraea, and Quercus macrocarpa Michx, showed $100 \%$ transferability to $Q$. robur, and a transferability of $70 \%$ to $C$. sativa.

The reported set of 20 polymorphic EST-SSRs can be used in future population genetic studies. Since all EST-SSRs were successfully annotated (Table 1), they might be especially useful for the investigation of adaptive processes in $Q$. rubra. 


\section{Acknowledgements}

We thank Alexandra Dolynska for assistance with the lab work and Elizabeth K. Jackson Davies for entering the genotypic data. Funding for the sampling of North American $Q$. rubra populations was provided by the Huron Mountain Wildlife Foundation and the USDA McIntire Stennis fund. Partial funding for the lab work was provided by the German Federal Ministry of Food and Agriculture (Funding code 22023314).

\section{References}

Altschul S.F., Madden T.L., Schäffer A.A., Zhang J., Zhang Z., Miller W., Lipman D.J. 1997. Gapped BLAST and PSI-BLAST: a new generation of protein database search programs. Nucleic Acids Research 25 (17): 3389-3402. DOI: 10.1093/nar/25.17.3389

Antao T., Lopes A., Lopes R.J., Beja-Pereira A., Luikart G. 2008. LOSITAN: a workbench to detect molecular adaptation based on a Fst-outlier method. BMC Bioinformatics 9: 323. DOI: 10.1186/1471-2105-9-323

Balding D.J. 2006. A tutorial on statistical methods for population association studies. Nature Reviews Genetics 7: 781-791. DOI: $10.1038 / \mathrm{nrg} 1916$

Barreneche T., Casasoli M., Russell K., Akkak A., Meddour H., Plomion C., Villani F., Kremer A. 2004. Comparative mapping between Quercus and Castanea using simple-sequence repeats (SSRs). Theor Appl Genet 108 (3): 558-566. DOI: $10.1007 / \mathrm{s} 00122-003-1462-2$

Bolte A., Ammer C., Löf M., Madsen P., Nabuurs G.-J., Schall P., Spathelf P., Rock J. 2009. Adaptive forest management in central Europe: Climate change impacts, strategies and integrative concept. Scandinavian Journal of Forest Research 24: 473-482. DOI: 10.1080/02827580903418224

Brownstein M.J., Carpten J.D., Smith J.R. 1996. Modulation of non-templated nucleotide addition by Taq DNA polymerase: primer modifications that facilitate genotyping. BioTechniques 20(6): 1004-1006, 1008-1010. DOI: $10.2144 / 96206 \mathrm{st} 01$

Earl D.A., vonHoldt B.M. 2012. STRUCTURE HARVESTER: a website and program for visualizing STRUCTURE output and implementing the Evanno method. Conservation of Genetic Resources 4(2): 359361. DOI: 10.1007/s12686-011-9548-7

Ellis J.R., Burke J.M. 2007. EST-SSRs as a resource for population genetic analyses. Heredity 99: 125. DOI: 10.1038/sj.hdy.6801001

European Environment Agency (EEA) 2012. Climate change, impact and vulnerability in Europe 2012, an indicator-based report. European Environment Agency, Copenhagen, $300 \mathrm{p}$.

Evanno G., Regnaut S., Goudet J. 2005. Detecting the number of clusters of individuals using the software STRUCTURE: a simulation study. Molecular Ecology 14(8): 2611-2620. DOI: 10.1111/j.1365294X.2005.02553.x

Giraudoux P. 2017. pgirmess: data analysis in ecology. R package version 1.6.7. Web: https://CRAN.R-project. org $/$ package $=$ pgirmess

Goudet J. 1995. FSTAT (Version 1.2): a computer program to calculate F-statistics. Journal of Heredity 86(6): 485486. DOI: 10.1093/oxfordjournals.jhered.a111627

Helyar S.J., Hemmer-Hansen J., Bekkevold D., Taylor M.I., Ogden R., Limborg M.T., Cariani A., Maes G.E., Diopere E., Carvalho G.R., Nielsen E.E. 2011. Application of SNPs for population genetics of nonmodel organisms: new opportunities and challenges. Molecular Ecology Resources 11: 123-136. DOI: 10.1111/j.17550998.2010.02943.x

Konar A., Choudhury O., Bullis R., Fiedler L., Kruser J.M., Stephens M.T., Gailing O., Schlarbaum S., Coggeshall M.V., Staton M.E., Carlson J.E., Emrich S., Romero-Severson J. 2017. High-quality genetic mapping with ddRADseq in the non-model tree Quercus rubra. BMC Genomics 18(1): 417. DOI: 10.1186/ s12864-017-3765-8

Kopelman N.M., Mayzel J., Jakobsson M., Rosenberg N.A., Mayrose I. 2015. CLUMPAK: a program for identifying clustering modes and packaging population structure inferences across K. Molecular Ecological Resources 15(5): 1179-1191. DOI: 10.1111/17550998.12387

Kubisiak T.L., Nelson C.D., Staton M.E., Zhebentyayeva T., Smith C., Olukolu B.A., Fang G.C., Hebard F.V., Anagnostakis S., Wheeler N., Sisco P.H., Abbott A.G., Sederoff R.R. 2013. A transcriptome-based genetic map of Chinese chestnut (Castanea mollissima) and identification of regions of segmental homology with peach (Prunus persica). Tree Genetics Genomes 9(2): 557571. DOI: $10.1007 / \mathrm{s} 11295-012-0579-3$

Lalagüe H., Csilléry K., Oddou-Muratorio S., Safrana J., de Quattro C., Fady B., González-Martínez S.C., Vendramin G.G. 2014. Nucleotide diversity and linkage disequilibrium at 58 stress response and phenology candidate genes in a European beech (Fagus sylvatica L.) population from southeastern France. Tree Genetics and Genomes 10(1): 15. DOI: 10.1007/s11295-013-0658-0

Lind J.F., Gailing O. 2013. Genetic structure of Quercus rubra L. and Quercus ellipsoidalis E. J. Hill populations at gene-based EST-SSR and nuclear SSR markers. Tree Genetics and Genomes 9(3): 707-722. DOI: 10.1007/ s11295-012-0586-4

Magni C.R., Ducousso A., Caron H., Petit R.J., Kremer A. 2005. Chloroplast DNA variation of Quercus rubra L. in North America and comparison with other Fagaceae. Molecular Ecology 14(2): 513-524. DOI: 10.1111/j.1365-294X.2005.02400.x 
Müller M., Finkeldey R. 2016. Genetic and adaptive trait variation in seedlings of European beech provenances from Northern Germany. Silvae Genetica 65(2): 65-73. DOI: $10.1515 / \mathrm{sg}-2016-0018$

Narum S.R., Hess J.E. 2011. Comparison of F(ST) outlier tests for SNP loci under selection. Molecular Ecology Resources 11: 184-194 . DOI: 10.1111/j.17550998.2011.02987.x

Peakall R., Smouse P.E. 2006. genalex 6: genetic analysis in Excel. Population genetic software for teaching and research. Molecular Ecology Notes 6 (1):288-295. DOI: 10.1111/j.1471-8286.2005.01155.x

Peakall R., Smouse P.E. 2012. GenAlEx 6.5: genetic analysis in Excel. Population genetic software for teaching and research - an update. Bioinformatics 28 (19):25372539. DOI: $10.1093 /$ bioinformatics/bts 460

Pritchard J.K., Stephens M., Donnelly P. 2000. Inference of population structure using multilocus genotype data. Genetics 155(2): 945-959.

Rellstab C., Gugerli F., Eckert A.J., Hancock A.M., Holderegger R. 2015. A practical guide to environmental association analysis in landscape genomics. Molecular Ecology 24(17): 4348-4370. DOI: 10.1111/mec. 13322

Rice W.R. 1989. Analyzing Tables of Statistical Tests. Evolution 43(1): 223-225. DOI: 10.1111/j.15585646.1989.tb04220.x

Roloff A., Grundmann B. 2008. Klimawandel und Baumarten-Verwendung für Waldökosysteme [Climate change and tree species use of forest ecosystems]. Technische Universität Dresden. Web: http://waldundklima. de/klima/klima_docs/swin_roloff_klam_2008.pdf. Accessed: 10.2018 .

Rousset F. 2008. genepop'007: a complete re-implementation of the genepop software for Windows and Linux. Molecular Ecological Resources 8(1): 103-106. DOI: 10.1111/j.1471-8286.2007.01931.x
Schuelke M. 2000. An economic method for the fluorescent labeling of PCR fragments. Nature Biotechnologies 18 (2):233-234. DOI: 10.1038/72708

Steinkellner H., Lexer C., Turetschek E., Glössl J. 1997. Conservation of (GA)n microsatellite loci between Quercus species. Molecular Ecology 6 (12):1189-1194. DOI: 10.1046/j.1365-294X.1997.00288.x

Sullivan A.R., Lind J.F., McCleary T.S., Romero-Severson J., Gailing O. 2013. Development and characterization of genomic and gene-based microsatellite markers in north American red oak species. Plant Molecular Biology Reporter 31(1): 231-239. DOI: 10.1007/s11105-0120495-6

The Hardwood Genomics Project. Web: https://hardwoodgenomics.org. Accessed: 10.2018.

USDA NRCS 2002. Plant guide, northern red oak (Quercus rubra L.). Web: https://plants.usda.gov/plantguide/ pdf/cs_quru.pdf. Accessed: 10.2018.

Weir B.S., Cockerham C.C. 1984. Estimating F-statistics for the analysis of population structure. Evolution 38 (6): 1358-1370.

\section{Supporting Information}

The online version of the article includes Supporting Information:

Table S1 Primers that did not amplify in $Q$. rubra

Figure S1 Plots of (a) $\Delta K$ and (b) log likelihood for each $K$ 